\title{
A IMPORTÂNCIA DAS PUBLICAÇÕES CIENTÍFICAS
}

Paulo Roberto Brofman ${ }^{1}$

As publicações científicas objetivam divulgar a pesquisa para a comunidade, de forma que permita que outros possam utilizá-la e avaliá-la sob outras visões. As revistas, eletrônicas ou impressas, ainda são consideradas como o modo mais rápido e economicamente viável, para os pesquisadores fazerem circular e tornar visíveis os resultados do seu trabalho. Pois, é por meio de uma publicação científica que a sociedade toma conhecimento dos resultados de um trabalho de pesquisa e o que este representa para a coletividade.

A democratização da ciência com a disponibilização dos artigos publicados na íntegra, nos periódicos científicos, ainda é cercada de polêmica. Algumas publicações alegam, que o dinheiro arrecadado com a taxa cobrada para se acessar o artigo na íntegra é para o financiamento da publicação. Entretanto, há iniciativas em sentido contrário, que cobra dos autores uma taxa para disponibilizar, gratuitamente, o conteúdo completo dos seus trabalhos na Internet. Outra alternativa, e bastante louvável, encontrada pela Coordenação de Aperfeiçoamento de Pessoal de Nível Superior - CAPES, foi o Portal de Periódicos, que dá acesso total ao conteúdo de 30.000 periódicos (números de 2011).

O aumento da produção científica no Brasil, país que atualmente ocupa a $13^{\circ}$ lugar na posição mundial, pode ser justificado pelo investimento na pós-graduação. Os números revelam que de 1996 a 2011 houve aumento do número de mestres e doutores, passando de 13,5 mil para 54,6 mil (42,2 mestres e 12,2 doutores).

Independentemente dos números, deve-se pensar na qualidade dessas publicações científicas, pois, fatores como problemas de ordem operacional ou estrutural, dificuldades de captação de conteúdo e mudanças políticas mal administradas no interior das organizações científicas podem minar com a "expectativa de vida" de um periódico.

O principal critério de existência de uma revista científica é ser amplamente lida e para isso, ela deve seguir alguns critérios: ter como objetivo ampliar os conhecimentos de uma área do saber, portanto ser específica; contar com um comitê editorial de especialistas capazes de assegurarem um alto nível de publicações; ser aberta a contribuições externas para garantir qualidade e competitividade; ser indexada; receber pedidos de assinaturas de instituições e pessoas físicas; receber pesquisas originais submetidas para publicação de autores externos e internos; ter seus artigos mencionados em outras publicações reconhecidas. Somente isso não vai assegurar que a publicação científica tenha sucesso, porém pode encaminhá-la para tal.

Outro fator que gera polêmica em torno das publicações científicas é a criação de uma revista que se apresenta com ambição científica, de caráter multidisciplinar e com comitê editorial e autores, em sua grande maioria, internos à própria instituição de ensino superior. Isto porque, ela servirá, basicamente, como meio fácil de publicar, podendo descomprometer a instituição e seus integrantes com a necessidade de aperfeiçoarem, permanentemente, seus trabalhos de investigação, gerando uma falsa sensação de produtividade científica, sem parâmetros externos de aferição.

Neste caso, recomenda-se que uma revista científica local deve ser a culminância de um projeto estratégico de uma instituição que valorize a pesquisa em todas as suas dimensões e complexidades, investindo tempo e dinheiro neste empreendimento, criando as condições necessárias para que seus alunos e professores realmente contribuam para a geração de novos conhecimentos nas diferentes áreas do saber.

Porém, todos esses critérios de qualidade, citados anteriormente, dificilmente serão aplicados sem investimento. Agências de fomento, instituições de ensino superior e órgãos estaduais e federais com a atribuição de financiar o desenvolvimento da ciência, tecnologia e inovação, devem ter o entendimento único de que tão importante quanto incentivar a produção científica e tecnológica é divulgar os resultados dessas pesquisas. E, principalmente, aplicá-los de forma que resultem em melhoria na qualidade de vida para a sociedade. Com base nisso, reconhecemos que o incentivo à publicação científica no Estado deveria ser ampliado, de forma que seja conhecida em todo país a produção e disseminação da ciência, tecnologia e inovação do Estado do Paraná.

\footnotetext{
${ }^{1}$ Médico. Doutor em Clínica Cirúrgica. Professor da Pontifícia Universidade Católica do Paraná. Presidente da Fundação Araucária Apoio ao Desenvolvimento Científico e Tecnológico do Paraná.
} 


\section{THE IMPORTANCE OF SCIENTIFIC PUBLICATIONS}

Paulo Roberto Brofman ${ }^{1}$

Scientific publications aim to disseminate research to the community, such that others may use it and evaluate it from different perspectives. Magazines - electronic or in print - are still considered the fastest and most economically viable means for researchers to circulate and visibilize the results of their work, as it is through scientific publication that society becomes aware of the results of research work and what it means for the community.

The democratization of Science, with the availability of articles being published in their entirety in scientific periodicals remains polemical. Some publications claim that the money raised with the fee charged to access the article in its entirety is for financing the publication. There are, however, initiatives in the opposite direction, charging authors a fee to make the complete content of their work available free of charge on the Internet. Another - fairly praiseworthy - alternative, encountered by the Coordination for Higher Education Staff Development (CAPES) was the CAPES Scientific Journals Gateway, which gives total access to the content of 30,000 periodicals (issues from 2011).

The increase in scientific production in Brazil - which currently stands in 13th place in the world ranking - may be explained by the investment in post-graduate education. The numbers show that from 1996 to 2011, there was an increase in the number of persons with MAs and PhDs, rising from 13,500 to 54,600 (42,200 MAs and $12,200 \mathrm{PhDs}$ )

Leaving the numbers to one side, one must consider these scientific publications' quality, as factors such as operational or structural problems, difficulty in attracting content, and poorly-administrated political changes within the scientific organizations can undermine a periodical's "life expectancy".

The principal criteria for a scientific magazine to exist is to be widely read, and for this, it must follow certain criteria: it must aim to widen knowledge in a particular area of study, so it must be specific; it must have an editorial committee comprised of specialists who are capable of ensuring a high level of publications; it must be open to external contributions, to guarantee quality and competitiveness; it must be indexed; it must be subscribed to by institutions and private individuals; it must receive original research submitted for publication by external and internal authors; its articles must be cited in other recognized publications. These factors alone will not ensure that the scientific publication is successful, but they will point it in the right direction.

The creation of magazines which are presented as having scientific aspirations, as having a multidisciplinary character, as having an editorial committee - and authors, the great majority of whom are internal to the institution itself - is another polemical factor in scientific publications. This is because such magazines serve, basically, as an easy way of publishing, which releases the institution and its members from the need to permanently improve their research work, creating a false sense of scientific production which, however, lacks external parameters for measurement.

In this case, it is recommended that a local scientific magazine should be the culmination of a strategic project of an institution which values research in all its dimensions and complexity, investing time and money in the endeavor, creating the conditions necessary for its students and teaching staff to genuinely contribute to the creation of new knowledge in different areas of learning.

All the quality criteria cited above, however, are unlikely to be applied without investment. Promotion agencies, higher education institutions and government or state bodies with the assignment of financing the development of science, technology and innovation, must have a unique understanding of how important it is to incentivize scientific and technological production and to disseminate the results of such research; and most of all, to apply the results in a way that results in improvement in the quality of life for society. On this basis, we recognize that the incentive for scientific publication in the State of Paraná should be broadened, such that the production and dissemination of the science, technology and innovation from the State of Paraná may be known across the whole of Brazil.

${ }^{1}$ Doctor. PhD in Surgery. Professor of the Pontifical Catholic University of Paraná. President of the Araucaria Foundation - Support for Scientific and Technological Development of Paraná.

Cogitare Enferm. 2012 Jul/Set; 17(3):419-21 


\section{LA IMPORTANCIA DE LAS PUBLICACIONES CIENTÍFICAS}

Paulo Roberto Brofman ${ }^{1}$

El objetivo de las publicaciones científicas es divulgar la investigación a la comunidad, para que otras personas puedan utilizarla y evaluarla bajo otros puntos de vista. Las revistas electrónicas o impresas son consideradas todavía el modo más rápido y economicamente viable para hacer circular y dar visibilidad a los resultados del trabajo de un investigador. Así, es por medio de una publicación científica que la sociedad toma conocimiento de los resultados de un trabajo de investigación y lo que este representa para la colectividad.

La democratización de la ciencia con la disponibilización de los artículos publicados en la íntegra en los periódicos científicos todavía genera polémica. Algunas publicaciones alegan que el dinero de la tasa cobrada para accesar el artículo en la íntegra es para la financiación de la publicación. Sin embargo, hay iniciativas en sentido contrario que cobran de los autores una tasa para disponibilizar gratuitamente el contenido completo de los trabajos en Internet. Una alternativa muy laudable de la Coordenação de Aperfeiçoamento de Pessoal de Nível Superior, CAPES, fue el Portal de Periódicos, que da acceso total al contenido de 30.000 periódicos (números de 2011).

El aumento de la producción científica en Brasil, país que actualmente ocupa la $13^{\text {a }}$ posición mundial, puede ser justificado por la inversión en el posgrado. Los números muestran que de 1996 a 2011, creció el número de mestres e doctores, pasando de 13,5 mil para 54,6 mil (42,2 mestres e 12,2 doctores).

Independientemente de los números, es necesario pensar en la cualidade de esas publicaciones científicas, pues, factores como problemas de orden operacional o estructural, dificultades de captación de contenido, cambios políticos administrados de modo malo en interior de las organizaciones científicas pueden minar la "expectativa de vida" de un periódico.

El principal criterio de existencia de una revista científica es el de ser esta muy leída. Para eso, se debe obedecer a algunos factores: tener como objetivo ampliar los conocimientos de un área del saber, por tanto ser específica; poseer un comité editorial de especialistas capaces de garantizar un alto nivel de publicaciones; ser abierta a contribucciones externas para asegurar cualidad y competitividad; ser indexada; recibir pedidos de suscripción de instituciones y personas físicas; recibir pesquisas originales sometidos para publicación de autores externos e internos; tener sus artículos mencionados en otras publicaciones reconocidas. Solamente eso no va a garantizar que la publicación científica tenga suceso, pero puede abrir camino para tal.

Otro factor que causa polémica acerca de las publicaciones científicas es la creación de una revista que presenta ambición científica, de carácter multidisciplinar y con comité editorial y autores en mayoría internos a la propia institución de enseñanza superior, ya que, así, habrá un medio más fácil de publicar, siendo posible descomprometer la institución y sus integrantes de la necesidad de perfeccionar permanentemente sus trabajos de investigación, generando una falsa sensación de productividad científica sin parámetros externos de evaluación.

En este caso, se recomienda que una revista científica local debe ser la meta de un proyecto estratégico de una institución que valora la investigación en todas sus dimensiones y complejidades, invertiendo tiempo y dinero en este emprendimiento, creando las condiciones necesarias para que sus alumnos y profesores realmente contribuyan para la generación de nuevos conocimientos en las distintas áreas del saber.

Sin embargo, los criterios de cualidade citados dificilmente serán aplicados sin inversión. Agencias de fomento, instituciones de enseñanza superior y órganos estaduales y federales con la atribución de financiar el desarrollo de la ciencia, tecnología e innovación deben entender que tan importante cuanto incentivar la producción científica y tecnológica es divulgar los resultados de esas investigaciones y, principalmente, aplicarlos de modo que resulten en mejoria en la cualidade de vida para la sociedad. Con base en esas ideas, reconocemos que el incentivo a la publicación científica en el Estado debría ser ampliado, para que sea reconocida en todo país la producción y diseminación de la ciencia, tecnología e innovación del Estado de Paraná.

\footnotetext{
${ }^{1}$ Médico. Doctor en Clínica Cirúgica. Profesor de la Pontifícia Universidade Católica do Paraná. Presidente de la Fundação Araucária - Apoyo al Desarrollo Científico y Tecnológico de Paraná.
} 